\title{
The Effect of Business Diversification on a Firm's Performance, Depending on Its Dynamic Capabilities and Market Dynamism
}

\author{
Young Sik Cho ${ }^{1}$ \\ ${ }^{1}$ Department of Management, College of Business Administration, The University of Texas-Pan American, Edinburg, \\ USA
}

Correspondence: Young Sik Cho, Department of Management, College of Business Administration, The University of Texas-Pan American, 1201 W. University Dr., Edinburg, TX 78539, USA. E-mail: ycho@utpa.edu

Received: July 12, 2013

Accepted: July 30, 2013

Online Published: August 1, 2013

doi:10.5430/jms.v4n3p1

URL: http://dx.doi.org/10.5430/jms.v4n3p1

\begin{abstract}
This study examines the relationships between a firm's business diversification, dynamic capabilities, and performance. In particular, using the lens of population ecological perspectives, the different effects of diversification on a firm's performance are investigated according to levels of market dynamism and the firm's dynamic capabilities. This study demonstrates that, in a rapidly changing market environment, the curvilinear relationship between diversification and firm performance can become weaker at higher levels of a firm's dynamic capabilities. In addition, this study argues that unrelated diversification can be a more ideal strategic choice in a dynamic market environment through a firm's optimized dynamic capabilities.
\end{abstract}

Keywords: business diversification, dynamic capabilities, market dynamism, a firm's structural inertia, population ecology

\section{Introduction}

Since the industrial revolution, many enterprises have emerged and greatly affected the history of capitalism; however, only a few initial enterprises have survived and continue to leave their mark on history. What differentiates surviving enterprises from extinct enterprises? One of the most powerful answers regarding this question could be "dynamic capabilities" (Teece, Pisano, \& Shuen, 1997). Teece et al. (1997: 516) originally defined dynamic capabilities as "the firm's ability to integrate, build, and reconfigure internal and external competences to address rapidly changing environments." Eisenhardt and Martin (2000) indicate that the traditional resource-based view (RBV) does not explain how and why a certain firm has a greater competitive advantage in a situation of rapid and unpredictable change. On the other hand, the 'dynamic RBV' school asserts that firms can be differentiated through their resource reconfiguration, thereby contributing to their competitive advantage. In fact, in the current rapidly changing market environment, the importance of a firm's dynamic capabilities is increasing. In addition, firms have a tendency to obtain their competitive advantage through diversification, particularly in situations of rapid change and unpredictable market environments. According to a study by Hitt, Ireland, and Hoskisson (2011), in an unstable market environment, firms tend to pursue related diversification to develop higher market power through economies of scope between their businesses, and unrelated diversification to create value in the financial economies involved in a "restructuring of assets" (Hitt et al.: 171). Hence, both a firm's dynamic capabilities and its diversification can be considered methods for enhancing its competitive advantage in an unpredictable, changing environment. In spite of the importance of a firm's dynamic capabilities for achieving a sustainable competitive advantage, the literature on the relationships between dynamic capabilities, diversification, and firm performance is underdeveloped. Therefore, this study aims to investigate how firms' dynamic capabilities and diversification impact their competitive advantage, particularly in a dynamic market environment, using the two lenses of the dynamic RBV and the population ecological approach. Specifically, this study intends to examine the following research questions:

(i) What is the relationship between dynamic capabilities and firm performance?

(ii) What is the relationship between diversification and firm performance?

(iii) What is the relationship between diversification and a firm's structural inertia?

(iv) How does market dynamism impact the relationships among dynamic capabilities, diversification, and firm performance? 


\section{The Relationships between Dynamic Capabilities, Diversification, and Firm Performance}

\subsection{What Are the Dynamic Capabilities of Firms?}

The original definition of dynamic capabilities (Teece et al., 1997: 516) is "the firm's ability to integrate, build, and reconfigure internal and external competences to address rapidly changing environments." Since Teece et al. (1997), many authors have offered their own definitions of dynamic capabilities by adapting Teece et al.'s original definition. Eisenhardt and Martin (2000: 1107) describe dynamic capabilities as "the firm's processes ... to integrate, reconfigure, gain and release resources - to match or even create market change." Zahra, Sapienza, and Davidsson (2006) recognize dynamic capabilities as "the abilities to reconfigure a firm's resources and routines in the manner envisioned and deemed appropriate by its principal decision-maker." In addition, Bowman and Ambrosini's (2003) study suggests four prime processes of dynamic capabilities: (i) reconfiguration, "the transformation and recombination of assets and resources"; (ii) leveraging, "replicating a process or system that is operating in one business unit to another"; (iii) learning, "an outcome of experimentation reflecting on failure or success"; and (iv) creative integration, "the ability of the firm to integrate its assets and resources, new resource configuration" (Ambrosini \& Bowman, 2009: 35).

\subsection{Dynamic Capabilities and Firm Performance}

According to previous studies, the relationship between dynamic capabilities and firm performance is complex (Wang \& Ahmed, 2007). First, Spanos and Lioukas's (2001) study shows that firm assets have a significant direct impact on market performance. Makadok (2001) recognizes dynamic capabilities as a casual mechanism through which firms accomplish economic rents or profits. Zollo and Winter's (2002) study suggests a direct link between dynamic capabilities and superior performance. Teece (2007: 1320) asserts that "the ambition of the dynamic capabilities framework is nothing less than to explain the sources of enterprise-level competitive advantage over time" and that "dynamic capabilities lie at the core of enterprise success."

On the other hand, some other studies have demonstrated an indirect relationship between dynamic capabilities and firm performances. Zott (2003) posits that dynamic capabilities are not directly linked to a firm's performance; in particular, he explains that dynamic capabilities indirectly impact a firm's performance by modifying its routines or resource bundle. Eisenhardt and Martin (2000) also assert that "long-term competitive advantage does not rely on dynamic capabilities themselves but on the resource configurations created by the dynamic capabilities" (Barreto, 2010: 263). As discussed, there is some dispute over whether dynamic capabilities and firm performance have a direct relationship or an indirect relationship; however, it seems less controversial and acceptable that a firm's dynamic capabilities have a positive impact on firm performance. Hence, I propose the following:

Proposition 1: Dynamic capabilities will be positively related to a firm's performance and the relationship between dynamic capabilities and the firm's performance will be likely to be a linear progression.

\subsection{Diversification and Firm Performance}

Palepu's (1985) study shows that firms with predominantly related diversification show significantly better profit growth than do firms with predominantly unrelated diversification. After synthesizing more than three decades of research using meta-analysis, Palich, Cardinal, and Miller (2000) suggest that moderate levels of diversification produce higher levels of performance than either single or unrelated diversification. These results seem to support the curvilinear model: firm performance increases as firms move from a single business strategy to related diversification but decreases as firms shift from related diversification to unrelated diversification. In addition, much other empirical evidence supports the curvilinear model directly or indirectly (e.g., Singh \& Montgomery, 1987; Markides, 1992; Lubatkin \& Chatterjee, 1994; Markides \& Williamson, 1994; Palich et al. 2000). 


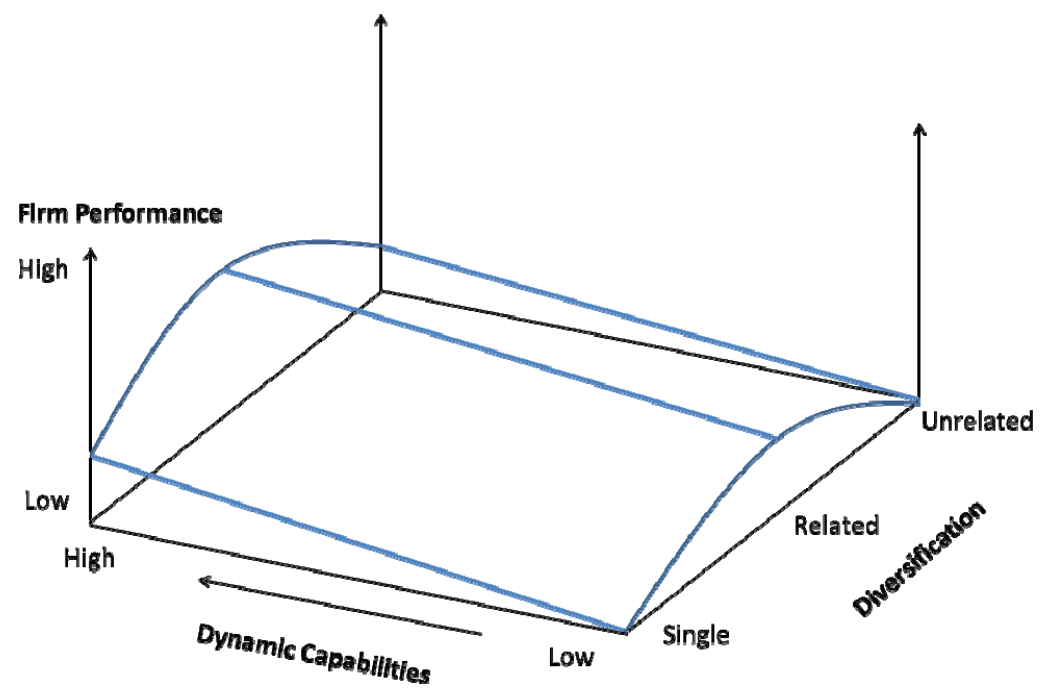

Figure 1. Relationships among dynamic capabilities, diversification, and firm performance in a stable market environment: Propositions 1 and 2

Figure 1 demonstrates the conceptualized model of the overall relationships among dynamic capabilities, diversification, and firm performance. Based on these arguments, the following is proposed:

Proposition 2: In a stable market environment, the relationship between diversification and a firm's performance will be curvilinear regardless of the firm's dynamic capabilities; related diversification will result in higher levels of performance than either single or unrelated diversification (an inverted $U$-shape).

\section{The Relationship between Diversification and a Firm's Structural Inertia}

\subsection{Population Ecological Approach to Organizations}

Population ecology theory is “an organizational version of Darwin's survival of the fittest principle; as in Darwin's theory of evolution, three processes - variation, selection, and retention-explain the dynamics of a population of organizations" (Hatch \& Cunliffe, 2006: 84). Organizational ecologists try to answer the fundamental question, "why are there so many kinds of organizations?” (Hannan \& Freeman, 1977: 936), by explaining how economic, social, and political conditions have an influence on the relative abundance and diversity of organizations. They also focus on accounting for composition changes over time (Hatch \& Cunliffe, 2006). Hannan and Freeman (1984) claim that organizational changes occur frequently, but the selection process is prone to favor organizations whose structures are difficult to change. High levels of structural inertia in organizations can thus be elucidated as an outcome of an ecological evolutionary process (Hannan \& Freeman, 1984; Young 1988). Furthermore, population ecology perspective essentially assumes that firms are subject to the significant power of the environment for their necessary resources. Specifically, the "selection (process) occurs as organizations that best fit the needs and demands of their ecological niche are supported with resources" (Hatch \& Cunliffe, 2006: 84).

\subsection{Diversification and a Firm's Structural Inertia}

With regard to firms' business diversification, a single diversification strategy can be defined as "a corporate-level strategy wherein the firm generates 95 percent or more of its sales revenue from its core business area" (Hitt et al., 2011: 159). If less than 70\% of revenue comes from the core business, and all businesses share technological and distribution linkages, it is considered a related diversification strategy (Rumelt, 1974). The primary purpose of related diversification is generally to gain market power relative to competitors by developing economies of scope (Hitt et al., 2011). On the other hand, if there is no direct link between businesses, it is regarded as an unrelated diversification strategy. The main purpose of an unrelated diversification strategy is to create value through "improved allocations of financial resources" (Hitt et al., 2011: 168) or "restructuring of assets" (Hitt et al., 2011: 171). Barnett and Freeman's (2001) study suggests that an organization's structural inertia increases when organizational practices and relationships become institutionalized. Considering the different purposes of diversification strategies, it is sensibly anticipated that firms pursuing unrelated diversification have fewer institutionalized practices and relationships between their businesses than do firms pursuing single or related diversification. In turn, it is also assumed that less institutionalization consequently contributes to lower structural 
inertia. Conversely, firms that seek single or related diversification might have a higher level of structural inertia than might firms pursuing an unrelated diversification strategy.

Table 1. Diversification intensity and a firm's structural inertia: Proposition 3

\begin{tabular}{lccc}
\hline & \multicolumn{3}{c}{ Diversification Intensity } \\
\cline { 2 - 4 } & Single & Related & Unrelated \\
\hline Level of Structural Inertia & High & Medium & Low
\end{tabular}

The relationship between diversification intensity and the organization's structural inertia is summarized in Table 1 . Based on these arguments, the following is proposed:

Proposition 3: Firms pursuing an unrelated diversification strategy have a lower level of structural inertia than do firms pursuing a single or related diversification strategy.

\section{The Relationships between Market Dynamism, Diversification, and Dynamic Capabilities}

\subsection{Dynamic Capabilities and Market Dynamism}

Eisenhardt and Martin (2000) indicate that the traditional RBV has not adequately explained how and why certain firms have competitive advantage in situations of rapid and unpredictable change. In contrast, the new paradigm of dynamic capabilities gives researchers a chance to address this issue by emphasizing the roles of managers. Amit and Schoemaker (1993) suggest that, in rapidly changing environments, the capability to reconfigure the firm's asset structure becomes an important advantage. Gran (1996) also explains that the manipulation of knowledge resources is notably critical in dynamic markets. In the same vein, Teece et al. (1997) explain that the dynamic capabilities of a firm, which enable a firm's managers to reconfigure internal and external competencies to address rapidly changing environments, become the source of sustained competitive advantage. Zollo and Winter's (2002) study demonstrates a direct link between dynamic capabilities and superior performance or survival in changing environmental conditions. In other words, their study implies that "both superiority and viability will prove transient for an organization that has no dynamic capabilities" (Zollo \& Winter, 2002: 341).

\subsection{Diversification and Market Dynamism}

Hannan and Freeman's (1984) study shows that a high level of structural inertia is negatively associated with firm survival in situations of a rapidly changing environment. Conversely, it is assumed that firms having a low level of structural inertia may have a higher chance for survival in a dynamic environment. As hypothesized already, firms pursuing an unrelated diversification strategy have a lower level of structural inertia than do firms pursuing a single or related diversification strategy. Therefore, it is mathematically induced that, in a rapidly changing environment, a firm engaging in unrelated diversification might be have more positive firm performance than a firm pursuing single or related diversification owing to lower structural inertia. Based on these discussions, the following proposition 4 is suggested:

Proposition 4: In a rapidly changing market environment, unrelated diversification is more positively related to a firm's performance than single or related diversification owing to the firm's lower structural inertia.

\subsection{The Relationship between Diversification and Dynamic Capabilities in a High-Velocity Market}

Eisenhardt \& Martin (2000) describe high-velocity markets as those with "ambiguous industry structures, fluid business models, blurred boundaries, and unpredictable change," and moderately dynamic markets as those with "stable industry structures, clear business models, defined boundaries, and predictable change" (p.1115). On the basis of these distinctions, Eisenhardt \& Martin (2000) assert that in a rapidly changing market, firms depend significantly on new knowledge created for specific situations, while in a moderately dynamic market, they rely extensively on detailed, analytic routines. As reviewed previously, a firm's dynamic capabilities can be characterized by the following four fundamental processes: reconfiguration, leveraging, learning, and creative integration (Bowman \& Ambrosini, 2003). Hence, considering the features of high-velocity markets and a firm's dynamic capabilities, it is obvious that a firm's dynamic capabilities may be more effective in a rapidly changing market situation. Ng's (2007) study indirectly supports this argument by suggesting that in incomplete markets the degree of diversification is positively related to an organization's weak ties and strength of its dynamic capabilities. $\mathrm{Ng}$ (2007) explains that "since weak ties promote the recombination of subjective experiences and provide access to unrelated resources, they change the discrete, indivisible, and heterogeneous nature of an organization's resource bundle; such changes in the resource bundle induce an organization with strong dynamic capabilities to seek the specialized growth of those 
unrelated resources and uses revealed by its weak ties" $(\mathrm{Ng}, 2007$ : 1490). On the basis of these arguments, it is suggested that in a high-velocity market environment, the traditional curvilinear relationship between diversification and firm performance (Palich et al. 2000) becomes weaker if a firm possesses high-level dynamic capabilities. Therefore, it is anticipated that a firm's dynamic capabilities may moderate the curvilinear relationship between diversification and firm performance under rapidly changing market conditions. Therefore, I suggest the following proposition 5:

Proposition 5: In a rapidly changing market environment, the curvilinear relationship between diversification and a firm's performance will become weaker at higher levels of dynamic capabilities.

Table 2. Relationship between market dynamism, diversification, and dynamic capabilities

\begin{tabular}{lccc}
\hline & \multicolumn{3}{c}{ Diversification Intensity } \\
\cline { 2 - 4 } & Single & Related & Unrelated \\
\hline $\begin{array}{l}\text { Effectiveness of Dynamic Capabilities in a } \\
\text { Stable Market Environment }\end{array}$ & Minimal & Mild & Minimal \\
\hline $\begin{array}{l}\text { Effectiveness of Dynamic Capabilities in a } \\
\text { Rapidly Changing Market Environment }\end{array}$ & Minimal & Moderate & Optimal \\
\hline
\end{tabular}

Table 2 summarizes the relationships between diversification, dynamic capabilities, and market dynamism. In addition, Figure 2 visualizes this study's conceptualized (theoretically proposed) relationships between dynamic capabilities, diversification, and firm performance in a rapidly changing environment.

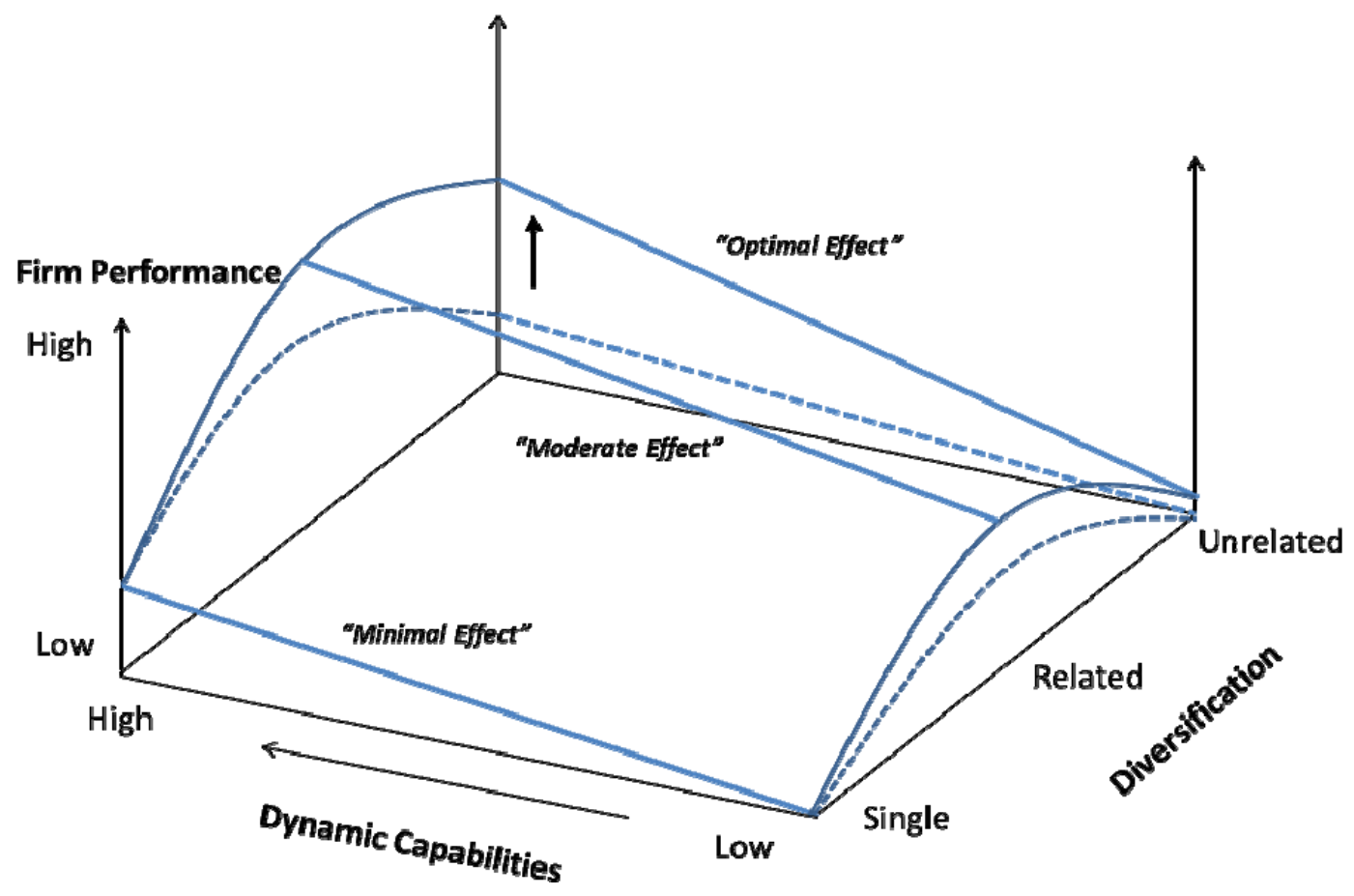

Figure 2. Relationships between dynamic capabilities, diversification, and firm performance in a rapidly changing market environment: Proposition 4 and 5

\section{Conclusion}

\subsection{Limitations}

This study has some limitations. Eisenhardt \& Martin (2000) indicate that, according to market dynamism, the causal ambiguity of dynamic capabilities occurs differently. In a stable market, the causal ambiguity of dynamic capabilities can be represented more significantly (Simonin, 1999) than in a dynamic market. Thus, it is very challenging "to isolate causality from the extensive but unimportant idiosyncratic details" (Eisenhardt \& Martin, 2000: 1114). However, the more critical challenge might come from the difficulty of measuring a firm's overall dynamic capabilities. For example, Wang \& Ahmed's (2007) study demonstrates that there are three component features of 
dynamic capabilities: adaptive, absorptive, and innovative capabilities. They also indicate that there are firm-specific processes of dynamic capabilities such integration, reconfiguration, renewal, and recreation (Wang \& Ahmed, 2007). Hence, it is assumed that the propositions suggested in this study should be restricted or revised if the empirical examination is conducted on a specific aspect of a firm's dynamic capabilities.

\subsection{Recommendations for Future Research}

In spite of these limitations, I anticipate that this study will make some meaningful contributions to the literature on strategic management. Theoretically, this study contributes to the strategic research field by integrating the existing the dynamic RBV literature with the literature on the population ecological perspective. In fact, this study was initially motivated by some fundamental questions related to evolutionary biology such as 'why some species flourished whereas others vanished as a result of the evolutionary processes on Earth?' and more specifically, 'why dinosaurs became extinct while homo sapiens survived during the evolutionary processes?' Evolutionary biologists are most likely to have well-defined answers to these questions. However, as a researcher in the field of management, I have drawn upon the concepts of dynamic capabilities and diversification to find answers to these questions. I believe that the one of the most significant factors for survival, and the primary feature that distinguished homo sapiens from dinosaurs, was the former's dynamic digestive capabilities and their ability to live on a mixed diet. In other words, homo sapiens had a well-evolved digestive system to take in a variety of natural food resources and transform them into energy needed to sustain life, eventually contributing to their survival in a rapidly changing environment through the process of natural selection. Reverting to our management discipline, Eisenthardt \& Martin (2000) argue that in high-velocity markets, the evolutionary emphasis is on selection, while in moderate markets, it is on variation. Considering all arguments discussed in this study, I strongly believe that we can learn many lessons from the evolutionary history of species on Earth. Therefore, I would recommend a more multidisciplinary approach towards any future research. Moreover, I would also strongly recommend a longitudinal study to investigate the conceptualized relationship among diversification, dynamic capabilities, and market dynamism, in any future research. Finally, I hope that the findings of this study facilitate firms or managers to make better strategic decisions in current hostile market environments in order to achieve sustainable competitive advantages.

\section{References}

Ambrosini, V., \& Bowman, C. (2009). What are dynamic capabilities and are they a useful construct in strategic management? International Journal of Management Reviews, 11(1), 29-49. http://dx.doi.org/10.1111/j.1468-2370.2008.00251.x

Amburgey, T. L., \& Miner, A. S. (1992). Strategic momentum: the effects of repetitive, positional, and contextual momentum on merger activity. Strategic Management Journal, 13(5), 335-49. http://dx.doi.org/10.1002/smj.4250130503

Amit, R., \& Schoemaker, P. (1993). Strategic assets and organizational rent, Strategic Management Journal, 14(1), 33-46. http://dx.doi.org/10.1002/smj.4250140105

Barkema, H. G., \& Vermeulen, F. (1998). International Expansion Through Start-Up Or Acquisition: A Learning Perspective. Academy Of Management Journal, 41(1), 7-26. http://dx.doi.org/10.2307/256894

Barretto, I. (2010). Dynamic capabilities: A review of past research and an agenda for the future. Journal of Management, 36(1), 256-280. http://dx.doi.org/10.1177/0149206309350776

Bettis, R. A., \& Hall, W. K. (1982). Diversification strategy, accounting determined risk, and accounting determined return. Academy of Management Journal, 25, 254-264. http://dx.doi.org/10.2307/255989

Bowman, C., \& Ambrosini, V. (2003). How the Resource-based and the Dynamic Capability Views of the Firm Inform Corporate-level Strategy. British Journal of Management, 14, 289-303. http://dx.doi.org/10.1111/j.1467-8551.2003.00380.x

Chatterjee, S., \& Wernerfelt, B. (1991). The link between resources and type of diversification: Theory and evidence. Strategic Management Journal, 33-48. http://dx.doi.org/10.1002/smj.4250120104

Christensen, H. K., \& Montgomery, C. A. (1981). Corporate economic performance: diversification strategy vs. market structure. Strategic Management Journat, 2, 327-343. http://dx.doi.org/10.1002/smj.4250020402

Eisenhardt, K., \& Martin, J. (2000). Dynamic capabilities: what are they? Strategic Management Journal, 21, 1105-1121. http://dx.doi.org/10.1002/1097-0266(200010/11)21:10/11<1105::AID-SMJ133>3.0.CO;2-E

Goold, M., \& Luchs, K. (1993). Why diversify? Four decades of management thinking. The Academy of 
Management Executive, 7(3), 7-25.

Grant, R. M. (1996). Toward a knowledge-based theory of the firm. Strategic Management Journal, 17, 109-122.

Hannan, M. T., \& Freeman, J. (1977). The population ecology of organizations. American Journal of Sociology, 82, 929-964. http://dx.doi.org/10.1086/226424

Hannan, M. T., \& Freeman, J. (1984). Structural inertia and organizational change. American Sociological Review, 49, 149-164. http://dx.doi.org/10.2307/2095567

Hatch, M. J., \& Cunliffe, A. L. (2006). Organization Theory: modern, symbolic, and postmodern perspectives (2nd ed.). New York: Oxford University Press.

Hill, C. W., \& Hansen, G. S. (1991). A longitudinal study of the cause and consequences of changes in diversification in the U.S. pharmaceutical industry 1977-1986. Strategic Management Journal, 12, 187-199. http://dx.doi.org/10.1002/smj.4250120303

Hitt, M. A., Hoskisson, R. E., \& Kim, H. (1997). International Diversification: Effects on Innovation and Firm Performance in Product-Diversified Firms. Academy Of Management Journal, 40(4), 767-798. http://dx.doi.org/10.2307/256948

Hitt, M. A., Ireland, R. D., \& Hoskisson, R. E. (2011). Strategic management: concepts: competitiveness \& globalization (9th ed.). Independence, KY: South-Western-Cengage.

Lubatkin, M. H., \& Chatterjee, S. (1994). Extending modern portfolio theory into the domain of corporate diversification: Does it apply? Academy of Management Journal, 37, 109-136. http://dx.doi.org/10.2307/256772

Makadok, R. (2001). Toward a synthesis of the resource-based and dynamic-capability views of rent creation. Strategic Management Journal, 22, 387-401. http://dx.doi.org/10.1002/smj.158

Markides, C. C. (1992). Consequence of corporate refocusing: Ex ante evidence. Academy of Management Journal, 35, 398-412. http://dx.doi.org/10.2307/256379

Markides, C. C., \& Williamson, P. J. (1994). Related diversification, core competencies and corporate performance. Strategic Management Journal, Summer Issue, 15, 149-165.

Michel, J. G., \& Hambrick, D. C. (1992). Diversification posture and top management team characteristics. Academy of Management Journal, 35, 9-37. http://dx.doi.org/10.2307/256471

Ng, D. W. (2007). A Modern Resource Based Approach to Unrelated Diversification. Journal of Management Studies, 44, 1481-1502. http://dx.doi.org/10.1111/j.1467-6486.2007.00719.x

Pablo, A., Reay, T., Dewald, J. R., \& Casebeer, A. L. (2007). Identifying, enabling and managing dynamic capabilities in the public sector. Journal of Management Studies, 44, 687-708. http://dx.doi.org/10.1111/j.1467-6486.2006.00675.x

Palepu, K. (1985). Diversification strategy, profit performance and the entropy measure. Strategic Management Journal, 6, 239-255. http://dx.doi.org/10.1002/smj.4250060305

Palich, L., Cardinal, L., \& Miller, C. (2000). Curvilinearity in the diversification-performance linkage: An examination of over three decades of research. Strategic Management Journal, 21, 155-174. http://dx.doi.org/10.1002/(SICI)1097-0266(200002)21:2<155::AID-SMJ82>3.0.CO;2-2

Park, C. (2002). The effects of prior performance on the choice between related and unrelated acquisitions: implications for the performance consequences of diversification strategy. Journal of Management Studies, 39(7), 1003-1019. http://dx.doi.org/10.1111/1467-6486.00321

Rumelt, R. P. (1974). Strategy, Structure, and Economic Performance. Cambridge, MA: Harvard University Press.

Simonin B. L. (1999). Ambiguity and the process of knowledge transfer in strategic alliances. Strategic Management Journal, $20(7)$,

595-623. http://dx.doi.org/10.1002/(SICI)1097-0266(199907)20:7<595::AID-SMJ47>3.3.CO;2-X

Singh, H., \& Montgomery, C. A. (1987). Corporate acquisition strategies and economic performance. Strategic Management Journal, 8(4), 377-386. http://dx.doi.org/10.1002/smj.4250080407

Singh, J. V. (1986). Performance, slack, and risk taking in organizational decision making. Academy of Management Journal, 29(3), 562-85. http://dx.doi.org/10.2307/256224 
Spanos, Y. E., \& Lioukas, S. (2001). An examination into the causal logic of rent generation: contrasting Porter's competitive strategy framework and the resource-based perspective. Strategic Management Journal, 22, 907-934. http://dx.doi.org/10.1002/smj.174

Teece, D. J. (2007). Explicating dynamic capabilities: The nature and microfoundations of sustainable enterprise performance. Strategic Management Journal, 28, 1319-1350. http://dx.doi.org/10.1002/smj.640

Teece, D., Pisano, G., \& Shuen, A. (1997). Dynamic capabilities and strategic management. Strategic Management Journal, 18, 509-533. http://dx.doi.org/10.1002/(SICI)1097-0266(199708)18:7<509::AID-SMJ882>3.0.CO;2-Z

Wang, K., \& Ahmad, P. (2007). Dynamic capabilities: A review and research agenda. International Journal of Management Reviews, 9(1), 31-51. http://dx.doi.org/10.1111/j.1468-2370.2007.00201.x

Young, R. (1988). Is population ecology a useful paradigm for the study of organizations? American Journal of Sociology, 94, 1-24. http://dx.doi.org/10.1086/228949

Zahra, S., Sapienza, H., \& Davidsson, P. (2006). Entrepreneurship and dynamic capabilities: a review, model and research agenda. Journal of Management Studies, 43, 917-955. http://dx.doi.org/10.1111/j.1467-6486.2006.00616.x

Zollo, M., \& Winter, S. G. (2002). Deliberate learning and the evolution of dynamic capabilities. Organization Science, 13, 339-351. http://dx.doi.org/10.1287/orsc.13.3.339.2780

Zott, C. (2003). Dynamic capabilities and the emergence of intraindustry differential firm performance: Insights from a simulation study. Strategic Management Journal, 24, 97-125. http://dx.doi.org/10.1002/smj.288

Zuniga-Vicente, J. A., \& Vicente-Lorente, J. D. (2006). Strategic moves and organizational survival in turbulent environments: The case of Spanish banks (1983-97). Journal of Management Studies, 43, 485-519. http://dx.doi.org/10.1111/j.1467-6486.2006.00599.x 